\title{
САМРЫН ЯСНЫ ПИРОЛИЗЫН СУДАЛГАА
}

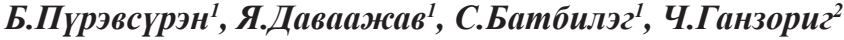 \\ ${ }^{1}$ ШУА-ийн Хими, хими технологийн хүрээлэн, \\ ${ }^{2}$ МУИС \\ purevsuren_b@yahoo.com
}

\section{ОРШИЛ}

Манай орны Хангай, Хэнтийн уульнн аглаг ойд ургадаг хуш модны самар нь хүнсний чухал бүтээгдэхүүн мөн хүнсний сайн чанарын тос гарган авч хэрэглэдэг. ХүмүҮс жил бүр их хэмжээгээр түҮж хүнсэнд хэрэглэхээс гадна нууцаар гадаад руу ихээр гаргадаг эх орны Унэт баялаг билээ. ХүмүҮс самрыг ихээр ияөж ясыг нь тааралдсан газраа хаяж гудамж талбай, байгаль орчноо ихээр бохирдуулдаг.

СҮҮлийн жилҮҮдэд бидний судалгааны ажльн нэг үндсэн чиглэл болох органик түҮхий эдүҮдийн пиролизын судалгаа [1]-ны хүрээнд байгалийн үндсэн органик түүхий эд болох төрөл бүрийн нүҮрс [2-6], занар [7-13], амьтны гаралтай иээвэр органик түҮхий эд сүҮний ээдэмиэр [14-23], зарим нэг хаягдал органик түүхий эдүүд болох мальн яс [2428], модны Үртэс [28], нэг удаагийн хэрэглэсэн тариур[29]-ууд зэрэг түҮхий эдүҮдийн пиролизын туршилтуудыг хийж гарган авсан хатуу,шингэн ба хийн бүтээгдэхүүнүҮдийн гари хэмжээг тогтоож тэдгээрийн техникийн иинж чанар, химийн бүрэлдэхүҮн ба хэрэглээний чиглэлийг тогтоох ажлуудыг үргэлжлүҮлэн хийж байна.

Иймд иөмөөд хаясан самрын яс нь органик хатуу хог хаягдал учраас түҮнийг пиролзын болон хагас коксжуулалтын аргаар боловсруулэ нүҮрсжссэн хатуу бүтээгдэхүҮн буюу хагас кокс, нефть төстэй шингэн давирхай ба шатдаг хий гарган авч болно гэж Үзээд дээр дурьдсан судалгааны чиглэлд хамруулан судлахаар иийдвэрлэсэн юм. Хэрвээ хаягдал самрын ясыг ямар нэг аргаар иуглуулж чадвал энэ аргаар боловсруулж хэрэгтэй бүтээгдэхүYн болгон ашиглаж болно тухайлбал нүүрсжссэн хатуу үлдэгдэл нь нүх сүвэрхэг бүтэитэй учир ицаашид усны хэт халсан уураар нэмэлт боловсруулалт хийж нүх сүвэрхэг чанарыг нь нэмэгдүҮлэн сайн чанарын шингээгч ба шүүгч материал болгон ашиглах бүрэн боложтойгоос гадна нэгэн төрлийн утаагүй шахмал түли байдлаар ч ашиглаж болно. Самрын ясны пиролизоор Үүссэн шингэн давирхай нь найрлагандаа олон янзын органик бодисуудыг агуулсан химийн үйлдвэрийн түүхий эд бөгөөд түҮнээс шатахуун тослох материал ч гарган авах боломжтой ба хийг нь шатдаг хий болгон ашиглаж болно. Иймд самрын ясны пиролизын судалгааг хийж хатуу, шингэн ба хийн бүтээгдэхүүнүҮдийн гариыьг нарийвчлан тогтоож нүҮрсжсэн хатуу үлдэгдлийн нүх сүвэрхэг чанарыг судлах зорилтыг энэхүу ажлаараа давшүүлэн тавьж ажиллав.

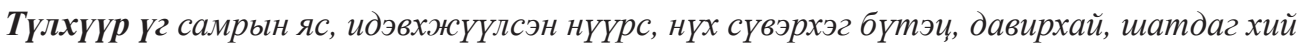

\section{СУДАЛГААНЫ МАТЕРИАЛ АРГА ЗУЙ}

Судалгааны объект болгож самрын хаягдал ясыг цуглуулан авч нунтаглан тасалгааны температурт хатаан аналитик дээж бэлтгэж техник ҮзүүлэлтүҮдийг холбогдох стандарт аргуудаар тухайлбал чийг-УСТ656-79, дэгдэмхий бодисын гарцУСТ654-79, үнслэг-УСТ652-79, илчлэгУСТ669-87 тус тус тодорхойлов.

Самрын ясны пиролизын цуврал туршилтуудыг үрмэл амтай лабораторийн 
жижиг стандартын кварцан реторт ба түүнтэй үрмэл амаар холбогдсон давирхай хүлээн авах зориулалтын халуунд тэсвэртэй шилэн хоолой мөн түүнтэй үрмэл амаар холбогдсон агаарын хөргөлттэй пиролизын усыг хүлээн авах зориулалттай шингэрээгүй хийнүүдийг гадагшлуулах нарийн гуурстай бөөрөнхий шилэн колбыг тус тус ашиглан гүйцэтгэв. Тасалгааны температурт хатаасан 0,2 мм-ээс томгүй ширхэгтэй 1 г. аналитик дээжийг кварцан ретортонд хийж лабораторийн жижиг цилиндр хэлбэрийн зууханд (халаалтын температурыг автомат температур тохируулагч потенциометрийн тусламжтайгаар тохируулна) хэвтээгээр байрлуулж халаана. Пиролизыг явуулахдаа тухайн сонгосон температур тухайлбал $600^{\circ} \mathrm{C}\left(200-800^{\circ} \mathrm{C}\right)$ хүртэл халаалтын тогтмол хурд $\left(20{ }^{\circ} \mathrm{C} /\right.$ мин. $)$-тайгаар халааж дараа нь энэ температурт 80 мин. үргэлжлүүлнэ. Пиролизоор үүссэн уур хийн хольц нь эхлээд $80^{\circ} \mathrm{C}$-ын тогтмол температур (температур тохируулагч латтер бүхий жижиг цлиндр зуухны тусламжтайгаар халаасан) бүхий давирхай тосогч шилэн хоолойгоор өнгөрөх явцдаа шингэрч халууны задралын шингэн бүтээгдэхүүн болох давирхай үүсэх ба энэ нөхцөлд пиролизын ус шингэрэхгүй бөгөөд халаалтгүй ус хүлээн авах колбонд орж байж шингэрнэ. Энэд шингэрээгүй хийнүүд нь тус колбоны хий гадагшлуулагч гуурсаар гадагшилна. Пиролизын хатуу үлдэгдэл, давирхай, пиролизын усны гарцыг жингийн аргаaр, шингэрээгүй хийн гарцыг ялгавараар тооцно.

Самрын ясны пиролизоор гарган авсан хатуу үлдэгдлийн нүх сүвэрхэг бүтцийг МУИС-ийн SEMTRAC SM-300 маркын Японы SEM электрон микроскопын тусламжтайгаар судлав.

\section{СУДАЛГААНЫ ҮР ДҮН}

Судалгааны объект болох самрын ясны аналитик дээжний чийг, үнс, дэгдэмхий бодис зэрэг техникийн үзүүлэлтүүдийг нүүрсний стандартын дагуу анх удаа тодорхойлж үр дүнгүүдийг 1-р хүснэгтэд үзүүлэв.

Самрын ясны техник анализын дүн

ХУснэгт 1

\begin{tabular}{|c|c|c|c|c|c|}
\hline Дээж & Чийг,\% & \multicolumn{2}{|c|}{ Үнслэг,\% } & \multicolumn{2}{|c|}{ Дэгдэмхий бодис, \% } \\
\hline \multirow{2}{*}{ Самрын яс } & $\mathrm{W}^{\mathrm{a}}$ & $\mathrm{A}^{\mathrm{a}}$ & $\mathrm{A}^{\mathrm{d}}$ & $\mathrm{V}^{\mathrm{a}}$ & $\mathrm{V}^{\mathrm{daf}}$ \\
\cline { 2 - 6 } & 5,58 & 0,74 & 0,78 & 73.87 & 78.85 \\
\hline
\end{tabular}

1-p хүснэгтээс үзэхэд самрын яс нь бараг үнсгүй цэвэр органик түүхий эд ба халаахад органик масс нь амархан задарч дэгдэмхий органик бодисуудыг ихээр Үүсгэж байгаа нь харагдаж байна.

Самрын ясны техник үзүүлэлтүүдийг ээдэмцэр, нүүрс, мод, малын яс зэрэг бусад органик түүхий эдүүдийнхтэй харьцуулан 2-р хүснэгтэд үзүүлэв.

ХУснэгт 2

Органик түҮхий эдҮҮдийн техник анализын дүн

\begin{tabular}{|c|c|c|c|c|c|c|c|}
\hline \multirow[t]{2}{*}{ № } & \multirow{2}{*}{ Органик түүхий эдүүд } & \multirow{2}{*}{$\begin{array}{c}\text { Чийг, } \\
\mathrm{W}^{\mathrm{a}}, \%\end{array}$} & \multicolumn{2}{|c|}{ Үнс } & \multicolumn{2}{|c|}{$\begin{array}{c}\text { Дэгдэмхий } \\
\text { бодисын гарц }\end{array}$} & \multirow{2}{*}{$\begin{array}{c}\text { Илчлэг, } \\
\mathrm{Q}^{\mathrm{daf}}, \text { ккал/кг }\end{array}$} \\
\hline & & & $\mathrm{A}^{\mathrm{a},} \%$ & $\mathrm{~A}^{\mathrm{d}, \%}$ & $\mathrm{~V}^{\mathrm{a}}$ & $\mathrm{V}^{\mathrm{daf}}$ & \\
\hline 1 & Ээдэмцэр & 8.73 & 4.72 & 5.17 & 67.75 & 78.28 & 5442.9 \\
\hline 2 & Таван тологойн нүүрс & 0.43 & 10.67 & 10.70 & 24.48 & 27.51 & 8192.27 \\
\hline 3 & Модны үртэс & 3.74 & 6.60 & 6.85 & 18.55 & 20.70 & 5270.9 \\
\hline 4 & Малын яс & 4.07 & 64.69 & 67.43 & 8.4 & 26.89 & 3611.5 \\
\hline 5 & Самрын яс & 5.58 & 0,74 & 0,78 & 73.87 & 78.85 & \\
\hline
\end{tabular}


2-p хүснэгтээс харахад ээдэмцэр ба малын яс нь амьтны гаралтай, самрын яс ба модны үртэс нь ургамалын гаралтай харин нүүрс нь амьтан ба ургамалын үлдэгдэл газрын хэвлийд олон мянган жил өөрчлөгдөн хувирах явцад үүссэн орнаик гаралтай түүхий эд юм. Эдгээрээс цэвэр органик түүхий эд болох самрын ясны үнслэг хамгийн бага, органик массын хэмжээ хамгийн их байгаагаараа онцлог байна. Хэдийгээр амьтны гаралтай цэвэр органик түүхий эд боловч ээдэмцэр ба малын яс нь найрлагандаa тухайлбал ээдэмцэрт $\mathrm{Ca}, \mathrm{P}$ тодорхой хэмжээгээр харин ясанд их хэмжээгээр байдгаараа онцлог. Модны үртэс нь мөн цэвэр органик түүхий эд учир үнслэг бага органик массын хэмжээ их байна. Харин нүүрс нь газрын хэвлийн органик түүхий эд учир үнслэг их органик массын хэмжээ харьцангуй бага байгаагаараа онцлог байна. Илчлэгийн хэмжээгээрээ Таван толгойн нүүрс бусдаасаа их байгаа нь түүний органик масс нь гүнзгий хувиралд орж нягтарсан бүтэцтэй учраас халуун тэсвэрлэх чанар нь бусдаасаа илүү байгаатай холбоотой гэж үзэж байна.

Самрын ясны дээжийг лабораторийн жижиг стандарт кварцан ретортонд пиролизын цуврал туршилтуддыг халаалтын янз бүрийн температурт (200$\left.800{ }^{\circ} \mathrm{C}\right)$ ижил халаалтын хурдтай $\left(20^{\circ} \mathrm{C} /\right.$ мин.)-гаар явуулж гарган авсан нүүрсжсэн хатуу үлдэгдэл, шиэнгэн давирхай ба хийн бүтээгдэхүүнүудийн гарцыг тодорхойлж 3-р хүснэгт ба 1-р зурагт тус тус үзүүлэв.

ХУснэгт 3

Самрын ясанд хийсэн кварцฺан ретортын пиролизын туршилтылн дүн

\begin{tabular}{|c|c|c|c|c|c|c|c|}
\hline \multirow{2}{*}{ Дээж } & $\begin{array}{c}\text { Дээжийн } \\
\text { жин,[гр] }\end{array}$ & $\mathrm{T}{ }^{0} \mathrm{C}$ & $\begin{array}{c}\mathrm{t}, \\
{[\text { мин] }}\end{array}$ & $\begin{array}{c}\text { Хатуу } \\
\text { Үлдэгдэл, } \\
\%\end{array}$ & $\begin{array}{c}\text { Давирхайн } \\
\text { гарц, \% }\end{array}$ & $\begin{array}{c}\text { Задралын } \\
\text { усны гарц, } \\
\%\end{array}$ & $\begin{array}{c}\text { Хий } \\
\text { алдагдал, } \\
\%\end{array}$ \\
\hline \multirow{4}{*}{$\begin{array}{c}\text { Самрын } \\
\text { яс }\end{array}$} & 1.0528 & 200 & 80 & 93 & 1.08 & 1.16 & 4.76 \\
\cline { 2 - 8 } & 1.0189 & 300 & 80 & 42.85 & 16.4 & 2.27 & 38.48 \\
\cline { 2 - 8 } & 1.0093 & 400 & 80 & 33.35 & 23.63 & 7.24 & 35.78 \\
\cline { 2 - 8 } & 1.0292 & 500 & 80 & 29.98 & 39.78 & 4.6 & 25.64 \\
\cline { 2 - 8 } & 1.0611 & 600 & 80 & 26.75 & 21.8 & 19.5 & 31.95 \\
\cline { 2 - 8 } & 1.0065 & 700 & 80 & 26.57 & 14.65 & 18 & 40.78 \\
\hline
\end{tabular}

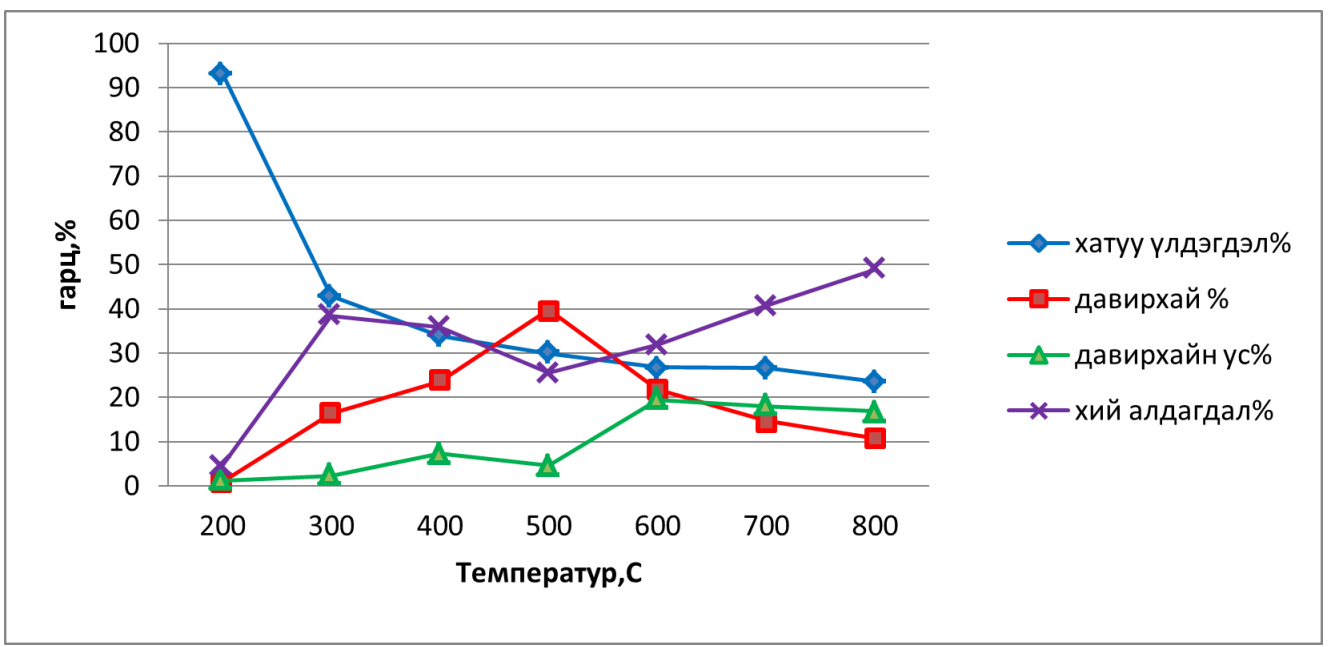

1-р зураг. Самрын ясны пиролизын бүтээгдэхүҮнүудийн гари ба халаалтын температурын хамаарал. 
Хүснэгт-1 ба 1-p зурагаас Үзэхэд халаалтын температурыг 200-аaс $800{ }^{\circ} \mathrm{C}$ хүртэл ихэсгэхэд самрын ясны органик массын халууны задралын дүнд пиролизын хатуу үлдэгдлийн гарц эрчимтэй буурч харин халууны задралаар үүссэн шингэн ба хийн бүтээгдэхүүний гарц тодорхой температур хүртэл тухайлбал давирхайных $500{ }^{\circ} \mathrm{C}$ ба задралын усных $600{ }^{\circ} \mathrm{C}$ хүртэл өсөөд цаашид буурч байна. Энэ нь эхлээд органик массын халууны задрал эрчимтэй өсөөд буурч байгаатай холбоотой. Пиролизын хийн бүтээгдэхүүний хувьд өндөр температурт тухайлбал $600-800^{\circ} \mathrm{C}$ нилээд өсөж байгаагаараа онцлог байна. Энэ нь өндөр температурт давирхайны зарим хэсэг задралд орж түүний гарц багасан хийн бүтээгдэхүүний гарцыг нэмэгдүүлсэн байна гэж үзэж болох юм.

Самрын ясны пиролзын эдгээр цуврал туршилтуудын дүнгээс үзэхэд халуун задралын дүнд нүх сүвэрхэг бүтэц сайтай шингээгч материал гарган авах боломжтойгоос гадна шингэн бүтээгдэхүүн давирхайн хувьд халаалтын хамгийн зохимжтой температурыг $500{ }^{\circ} \mathrm{C}$ гэж үзэж болохоор байна.

Ингээд халаалтын температур 500 ${ }^{\circ} \mathrm{C}-\Gamma$ хамгийн зохимжтой гэж үзээд энэ температурт дахин пиролизын томруулсан цуврал туршилтуудыг өөрсдийн зохион бүтээсэн 1кг дээжний багтаамжтай ган ретортын тусламжтайгаар явуулж гарган авсан бүтээгдэхүүнүүдийн гарцыг 4-p хүснэгтэд үзүүлэв.

ХУснэгт 4

Томруулсан туршилтын пиролизын бүтээгдэхүҮний гари

\begin{tabular}{|c|c|c|c|c|}
\hline № & Температур, ${ }^{\circ} \mathrm{C}$ & $\begin{array}{c}\text { Хатуу } \\
\text { үлдэгдэл, \% }\end{array}$ & $\begin{array}{c}\text { Давирхай ба } \\
\text { ус, \% }\end{array}$ & $\begin{array}{c}\text { Хий ба алдагдал, } \\
\%\end{array}$ \\
\hline 1 & \multirow{3}{*}{500} & 35,53 & 39,71 & 24,76 \\
\hline 2 & & 36,04 & 39,53 & 24,43 \\
\hline 3 & & 34,00 & 39,59 & 26,41 \\
\hline Дундаж & 500 & 35,19 & 39,61 & 25,20 \\
\hline
\end{tabular}

4-p хүснэгтээс үзэхэд 3-р хүснэгтэд $500{ }^{\circ} \mathrm{C}$-д ажиглагдаж байсан хатуу,шингэн ба хийн бүтээгдэхүүнүүдийн гарц ойролцоогоор давтагдсан гэж үзэж болохоор байна.

Иймд самрын ясыг $500 \quad{ }^{\circ} \mathrm{C}$-ын температурт $20^{\circ} \mathrm{C} /$ мин. хурдтайгаар халааж пиролизыг 80 минутын туршид явуулахад нүүрсжсэн хатуу үлдэгдлийг 30 гаруй \%-ийн гарцтайгаар гарган авч болохоос гадна нефть төстэй шингэн бүтээгдэхүүн болох давирхайн гарц хамгийн их буюу $35-40 \%$ ийн гарцтайгаар гарган авах боломжтойг тогтоов. Самрын ясны пиролизын хамгийн чухал бүтээгдэхүүн болох нүүрсжсэн хатуу үлдэгдлийн техник үзүүлэлтүүдийг тодорхойлж үр дүнг 5-р хүснэтэд үзүүлэв.

Пиролизын хатуу үлдэгдлийн техник анализын дүн

ХУснэгт 5

\begin{tabular}{|c|c|c|c|c|c|}
\hline Дээж & Чийг,\% & \multicolumn{2}{|c|}{ Үнслэг,\% } & \multicolumn{2}{c|}{ Дэгдэмхий бодис, \% } \\
\hline \multirow{2}{*}{ Самрын яс } & $\mathrm{W}^{\mathrm{a}}$ & $\mathrm{A}^{\mathrm{a}}$ & $\mathrm{A}^{\mathrm{d}}$ & $\mathrm{V}^{\mathrm{a}}$ & $\mathrm{V}^{\mathrm{daf}}$ \\
\cline { 2 - 6 } & 0,79 & 5,68 & 5,73 & 16,18 & 17,29 \\
\hline
\end{tabular}

4-p хүснэгтээс үзэхэд самрын ясны пиролизын хатуу үлдэгдлийн үнслэг ихэссэн нь хагас коксын полимержиж нүүрсжсэн хэсэг бөгөөд дэгдэмхий бодисын хэмжээ бараг 4 дахин буурсан байна. Ингэж гаргаж авсан нүүрсжсэн хатуу үлдэгдлийн нүх сүвэрхэг бүтэц байгууламжийг орчин үеийн өндөр мэдрэмжтэй SEM электрон микроскопын тусламжтайгаар судалж гарган авсан янз бүрийн хэмжээгээр томсгосон зурагуудыг 2-р зурагт үзүүлэв. 

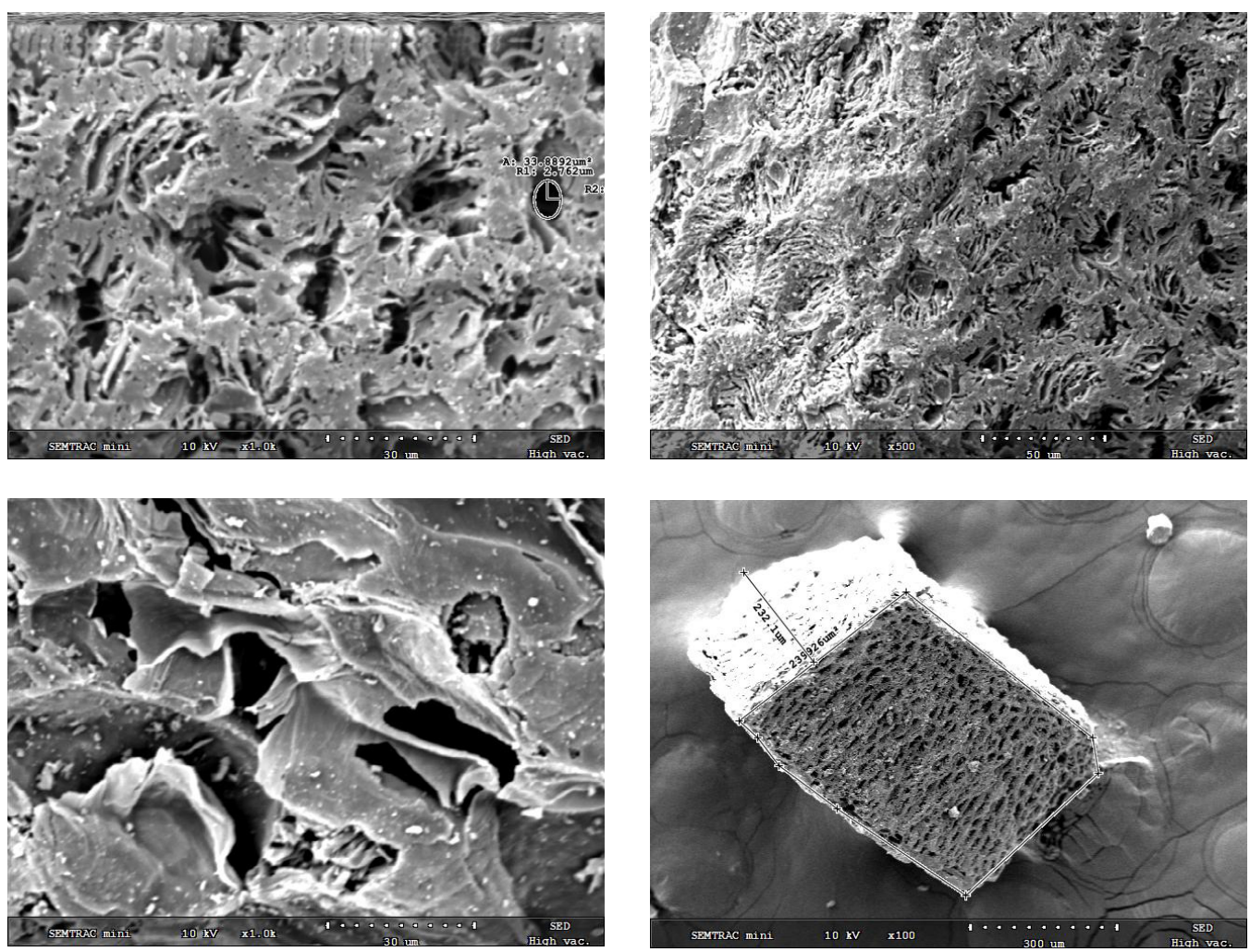

2-р зураг. Самрын ясны пиролизын хатуу үлдэгдлийн янз бүрийн хэмжээгээр томсгосон электрон микроскопын (SEM) зургууд.

2-p зурагаас үзэхэд самрын ясны пиролизын хатуу үлдэгдлийн нүх сүвүүд бүх талбайгаараа болон орон зайн хувьд жигд тархсан маш сайн хөгжсөн харьцангуй бага хэмжээстэй байгаагаараа онцлог байгаа ба сайн чанарын шингээгч ба шүүгч материал болгон ашглах боломжтойг нь баталж байна.

\section{ДҮГНЭЛТ}

1.Самрын ясны техник үзүүлэлтүүдийг анх удаа тодорхойлж тэрээр бараг үнсгүй цэвэр органик түүхий эд ба халаахад органик масс нь амархан задарч дэгдэмхий органик бодисуудыг ихээр үүсгэж байгааг тогтоов.

2. Самрын ясны пиролизын туршилтуудыг анх удаа явуулж $500{ }^{\circ} \mathrm{C}$-ын температурт $20^{\circ} \mathrm{C} /$ мин. хурдтайгаар халааж пиролизыг 80 минутын туршид явуулахад нүүрсжсэн хатуу үлдэгдлийг 30 гаруй \%-ийн гарцтайгаар гарган авч болохоос гадна нефть төстэй шингэн бүтээгдэхүүн болох давирхайн гарц хамгийн их буюу $35-40 \%$ ийн гарцтайгаар гарган авах боломжтойг тогтоов.

3. Самрын хаягдал ясны пиролизын хатуу үлдэгдлийн нүх сүвэрхэг бүтцийг орчин үеийн өндөр тэдрэмжтэй электрон микроскопын (SEM) аргаар судалж нүх сүвүүд нь бүх талбайгаараа болон орон зайн хувьд жигд тархсан маш сайн хөгжсөн харьцангуй бага хэмжээстэй байгаагаараа онцлог байгаа ба сайн чанарын шингээгч ба шүүгч материал болгон ашглах боломжтойг нь баталж байна. 


\section{Ашигласан бүтээлийн жагсаалт}

1. Б.Пүрэвсүрэн, Я.Даваажав. Органик түүхий эдүүдийн пиролизын судалгаа, Монограф, "Тоонот принт” хэвлэлийн газар, 2006, х.196 (15 хэвлэлийн хуудас).

2. Б.Пүрэвсүрэн,Ж.Нарангэрэл,Д.Балжир.Багануурын хүрэн нүүрсийг өндөр хурдтай пиролизын аргаар судалсан дүн.ШУА-ийн мэдээ,1999 он, №2, х.32-37.

3. B.Avid, B.Purevsuren, N.Paterson, Y.Zhuo, D.Peralta, A.Herod, D.Dugwell,R.Kandioty, An exploratory investigation on the perfomence of Shivee-Ovoo coal and Khoot oil shale from Mongolia, Fuel, 83 (2004): 1105-1111.

4. B.Avid, B.Purevsuren et al. Pyrolysis and TG analysis of the Shivee Ovoo coal Mongolia, Journal of Thermal Analysis and Calorimetry, Vol.68 (2002), pp.877-885.

5. B.Avid, Y.Sato, K.Maruyama, Y. Yamada, B.Purevsuren, Effective utilization of Mongolian coal by upgrading in a solvent. Fuel processing technology, 85, (2004) 933-945.

6. Б.Пүрэвсүрэн,Ж.Нарангэрэл,Д.Дэнсмаа.Багануурын нүүрсний давирхайны бүтэц, МУИС-ийн Химийн факультет, Эрдэм шинжилгээний бичиг Хими №3 (175),2001он, х.91-96.

7. B.Avid, B.Purevsuren,J.Dugarjav. Pyrolysis and thermogravimetrical investigation of the Mongolian Khoot oil shale.Oil shale, 2000,vol.17, №3,p.241-251.

8. B.Avid, B.Purevsuren. Chemical composition of organic matter of the Mongolian Khoot oil shale, Oil shale, 2001, Vol.18, №1,pp.18-23.

9. B.Avid, B.Purevsuren. Investigation of mineral matter of the Mongolian Khoot oil shale, Oil shale, 2002, Vol.19, №1, pp.35-42.

10. B.Avid, M.Born, B.Purevsuren, N.Undrakh, A.Tuvshinjargal. Thermal behavior of the Khoot oil shale in the different conditions, Oil shale,2003,vol.20, №1, p.47-55.

11. B.Avid,B.Purevsuren, J.Dugarjav. Investigation on the pyrolysis of Mongolian oil shale and its thermogravimetric analysis, Proceedings of the MAS,Ulaanbaatar,1999, №3, p.23-30 (in English).

12. Я.Даваажав, Б.Пүрэвсүрэн, Б.Авид, Б.Ширчин. Занарын пиролизын давирхайны химийн бүрэлдэхүҮн, ШУА-ын мэдээ,Дугаар 176, № 02, 2005, х.9-23.

13. B.Avid,B.Purevsuren, J.Dugarjav. Investigation on the pyrolysis of Mongolian oil shale and its thermogravimetric analysis, Proceedings of the MAS,Ulaanbaatar,1999, №3, p.23-30 (in English).

14. B.Purevsuren and Ya.Davaajav. Thermal analysis of casein, Journal of Thermal Analysis and Calorimetry, Vol.65 (2001), pp.147-152.

15. B.Purevsuren, Ya.Davaajav. Investigation on pyrolysis of casein, Journal of Thermal Analysis and Calorimetry, Vol.66, (2001), pp.743-748.

16. B.Purevsuren, B.Avid, Ya.Davaajav, A.Herod, R.Kandiyoti, T.J.Morgan. Estimation of the molecular mass range of the tar from pyrolysis of casein by gas chromatography-mass spectrometry, probe mass spectrometry and size-exclusion chromatography with 1-methyl-2-pyrrolidinone as eluent. European Journal of Mass Spectrometry, 10, 101-108 (2004).

17. B.Purevsuren,B.Avid. Pyrolysis of casein and properties of its products. Reports of the Institute of Chemistry and chemical technology, Mongolian Academy of Sciences,1998,p.29-32 (in English).

18. B.Purevsuren,Ya.Davaajav.The pyrolysis hard residue and mineral composition of casein. Proceedings of the Mongolian Academy of Sciences, Ulaanbaatar,1999,№1,vol.151,p.40-45 (in English).

19. B.Purevsuren, Ya.Davaajav. Investigation on pyrolysis of casein, Proceedings of the MAS, Uaanbaatar,2001, №2 ,p.6-12 (in English).

20. С.Энхтуул, Д.Бадарч, Б.Пүрэвсүрэн. Ээдэмцэрийн шингээгчийн судалгаа. ХХТХ-ийн бүтээл, 2004 он, № 5(31),х.95-100.

21. Я.Даваажав, Б.Пүрэвсүрэн. Ээдэмцэрийн пиролизын давирхайны химийн бүрэлдэхүүн, 
ШУТИС-ийн Материалын Технологийн Сургуулийн эрдэм шинжилгээний бичиг, № $3 \backslash 83,2006$, x. 86-94.

22. Iv.Glavchev, B.Purevsuren, R.Ganev, P.Novakov. Relation between permahor and degradbility of polymers, Journal of the University of Chemical Technology and Metallurgy, XXXVII, 1 (2002), p.95-98.

23. B.Purevsuren, B.Avid, B.Tesche,Ya.Davaajav. A biochar from casein and its properties, Journal of Material Science, 38, № 11, ( 2003) 2347-2351.

24. B.Purevsuren, B.Avid, T.Gerelmaa, Ya.Davaajav T.J,Morgan, A.Herod, R.Kandiyoti. The characterization of tar from pyrolysis of animal bones, Fuel 83 (2004) 799-805.

25. B.Purevsuren, B.Avid, J.Narangerel, T.Gerelmaa, Ya.Davaajav. Investigation on the pyrolysis products from animal bone, Journal of materials science 39 ( 2004) 737-740.

26. Б.Пүрэвсүрэн, Т.Гэрэлмаа, С.Энхтуул, Я.Даваажав.Ясны пиролизын судалгааны дүнгээс. ШУА-ийн мэдээ, 2001 он, №1,х.13-19.

27. Я.Даваажав, Б.Пүрэвсүрэн. Ясны пиролизын давирхайны химийн бүрэлдэхүүн, ШУТИС-ийн Материалын Технологийн Сургуулийн эрдэм шинжилгээний бичиг, № 3/83, 2006, x. 98-104.

28. Sh.Munkhjargal,B.Purevsuren and et al. Products of pyrolysis of wood wastes, Reports of the Institute of Chemistry and chemical technology,Mongolian Academy of Sciences, 1998,p.2528 (in English).

29. B.Purevsuren, Ya.Davaajav, F.Karaca, T.J.Morgan, A.George, A.A.Herod, R.Kandiyoti, Pyrolysis of waste polypropylene and characterization of the tar, European Journal of Mass Spectrometry, 2009; 15(1): 23-33. 


\title{
INVESTIGATION ON PYROLYSIS \\ OF WASTE OF CEDAR SHELL
}

\author{
B.Purevsuren ${ }^{1}$, Ya.Davaajav ${ }^{1}$, S.Batbileg ${ }^{1}$, Ch.Ganzorig ${ }^{2}$ \\ I-Institute of Chemistry and Chemical Technology, MAS \\ ${ }^{2}-$ Mongolian National State University
}

The waste of cedar shell was the object of pyrolysis experiments. The technical characteristics of waste of cedar shell have been determined for first time and compared with technical characteristics of other organic raw materials such as coal, oil shall, casein, animal bone and plastic waste. Have been determined an optimal condition for pyrolysis of waste of cedar shell (heating temperature $-500^{\circ} \mathrm{C}$, heating rate $-20^{\circ} \mathrm{C} / \mathrm{min}$, time of pyrolysis- $80 \mathrm{~min}$.) and determined the yields of pyrolysis products including hard residue, tar, pyrolysis water and gases. The porosity structure of hard residue determined by the SEM analysis. 